\title{
Antibacterial Activity of The Hexane Extract from Leaf of Plant Solanum Ferox L
}

\author{
Hazimah $^{1}$, Zefri Azharman $^{2}$, Yuharmen $^{3}$, Virsa Rahyuti ${ }^{4}$, and Afriliani ${ }^{5}$ \\ \{hazimahima1987@gmail.com¹, zefriazharman91@gmail.com², yu63muras@gmail.com³, \\ virsarahyuti@gmail.com ${ }^{4}$, afriliani@gmail.com $\left.{ }^{5}\right\}$ \\ Department of Industrial Engineering, University of PuteraBatam, Batam, 29439, Indonesia ${ }^{1}$, \\ Departement of Organic Chemistry, University of Riau, Pekanbaru, Riau, 28293, Indonesia ${ }^{2,3,4,5}$.
}

\begin{abstract}
Solanum ferox or Acid aubergine plants is one of the vegetables that are made in the food. Solanum ferox contains terpenoid compounds, steroids, flavonoids, alkaloids, and phenolics. Solanum ferox has antipyretic active compounds, antirheumatic, antiasthma, antiviral, and as a syphilis drug. The purpose of this research is the antibacterial activity of Solanum ferox plant leaf extract. Solanum ferox leaves are extracted using n-hexane. The extract was tested for antibacterial activity using a diffusion method to use E.coli, S.aureus and B.subtilis bacteria. Amoxicillin is used as a positive standard, whereas negative control is the solvent used to dissolve the sample. The antibacterial activity of n-hexane extract and amoxicillin showed inhibitory zone to E.coli of $7.80-12.93 \mathrm{~mm}$ and $19.97 \mathrm{~mm}$, whereas in S.aureus and B.subtilis did not provide inhibition zone.
\end{abstract}

Keywords: Solanum ferox, E.coli, S.aureus, B.subtilis, Antibacterial.

\section{Introduction}

Humans are often infected with various microorganisms such as bacteria, fungi, yeast, and viruses that exist in our environment. This is due to an increase in the number of antibioticresistant microorganisms and the cost of health care costs, many scientists have examined methods for developing new effective antimicrobial agents that overcome microorganism resistance and are also cost-effective(Hwan et. al., 2011)].

Infectious diseases are a major cause of global morbidity and mortality. In 1990, the infection caused 16 million deaths, and by 2010, the number of deaths has dropped to 15 million. The spread of infectious diseases resulted in many changes from human behavior, included lifestyle and land use patterns, increased trade and travel, and inappropriate use of antibiotic drugs such as mutations in pathogens. Staphylococcus aureus, Escherichia coli and Bacillus subtilis are the main causes of various human and animal infections that cause skin and soft tissue infections, surgical site infections, and bone and joint infections. Staphylococcus aureus is a common cause of hospital-acquired bacteremia and is associated with acquired respiratory infections in the hospital. E. coli is the most common cause of urinary tract infection (UTI) in humansand is a major cause of enteric and systemic infections. Systemic infections include bacteremia, nosocomial pneumonia, cholecystitis, cholangitis, peritonitis, cellulitis, osteomyelitis, and infectious arthritis. E.coli is also a major cause of neonatal meningitis. A variety of antimicrobial agents effectively inhibit E.coli growthBachir 
and Abouni, 2015). Another bacterium that causes infectious disease is Bacillus subtilis. A large amount in the intestine would cause diarrhea that was transmitted through food contamination (Griffith \& Grossman, 2008).

The acid aubergine(Solanum ferox L) is one type of vegetable which often used as a flavoring in cooking, the acidic eggplant is included in the Solanaceae family and includes three main food crops (Abdullah, et.al., 2012).Solanaceae is a family of flowering plants, which consists of about 100 genera and 2500 species (Olmstead, et.al., 2008). Solanaceae is one of the most valuable and varied families among vegetables, and this family has many uses. Several plant species of economically viable Solanaceae become an important system pilot in biological plant research to study crop development, fruit maturation and food security[6].

Previous research showed that Solanum ferox-consisted of terpenoid compounds, such as teroids, flavonoids, alkaloids, and phenolics. Literary studies show that Solanum ferox L can be used for syphilis, antipyretic, antirheumatic, antiaxia, antiviral, and anticancer drugs (Joy, et.al., 2001). In one study also showed that the Solanum ferox plant has a variety of bioactive compounds that are antibacterial(Rahman, et.al., 2008), antirematics, anti-inflammatory, antiviral, anticancer[7] and toxic (Andullah, et.al., 2012). Based on the interest of Solanum ferox then conducted a study to see the antibacterial activity of Solanum ferox plant leaves.

\section{The Material And Method}

\subsection{The Materials}

The instrument was kept in the sterile box, petri dish, ose needle, vial, aluminum voil, and glass tools commonly used in the laborato-ry. Materials used include methanol, n-hexane, nutrient agar (NA), nutrient broth (NB), Amoxsan ${ }^{\circledR}$ antibiotics, cotton, aluminum foil and aquades.

\subsection{Gel media preparation.}

The media used for the antibacterial test are NA (nutrient agar). The process of preparing, the amount of $20 \mathrm{gr}$ of mediawas provided and dissolved in $1000 \mathrm{~mL}$ of aquadest and fed into the reaction tube, each of which was $15 \mathrm{~mL}$. The media was closed and sterilized at a temperature of $1210 \mathrm{C}$ and a pressure of 15 psi for 15 minutes

A PDA of 39 grams was dissolved in $1000 \mathrm{~mL}$ of aquades and then the media was fed into the reaction tube, each of which was $15 \mathrm{~mL}$. The media was closed and sterilized at a temperature of $1210 \mathrm{C}$ and a pressure of 15 psi for 15 minutes.

\subsection{Microbial Rejuvenation}

Microbial rejuvenation aims to rejuvenate bacteria (S.aureus, E.coli, and B.subtilis) from in order to tilt into the NB solution. NB media that have been made are put into a test tube and sterilized. The bacteria from oblique agar were taken using a sterile needle, then inoculated into the NB medium. The tube was covered with cotton and then incubated in an incubator at $370 \mathrm{C}$ for 24 hours. 


\subsection{Antibacterial Test}

The medium was heated to be melted and cooled to a temperature of $500 \mathrm{C}$ in a waterbath. Thus, added $1 \mathrm{~mL}$ of bacterial culture of E.coli, S.aureusand B.subtilis (OD600 nm $\square 0,1$ into tube, then homoge-nized and poured into petri dishes.) After the media solidified, $(0.9 \mathrm{mg} / \mathrm{mL}$, $3.8 \mathrm{mg} / \mathrm{mL}$ and $5.7 \mathrm{mg} / \mathrm{mL}$ ) were placed on positive agar medium, Amoxsan with concentration of $3.8 \mathrm{mg} / \mathrm{mL}$ and negative con-trol of solvent used to dissolve the sample petri dish-es were incubated in incubator at 370C. The diameter of bacterial growth inhibition area was measured after incubation for 24 hours All treatment was done aseptically and repeated twice.

\section{Result And Discussion}

Antibacterial activity test was performed on $n$-hexane extract with concentrations of 1.9 $\mu \mathrm{g} / \mathrm{ml}, 3.8 \mu \mathrm{g} / \mathrm{ml}$ and $5.7 \mu \mathrm{g} / \mathrm{mlof}$ Escherichia coli, Staphylo-coccus aureus and Bacillus subtilis bacteria. Anti-bacterial activity test from total extract of n-hexane showed the inhibitory zone diameter against E.coli bacteria while S.ausreus and B.subtiliswere not able to inhibit bacterial growth. This can be seen in Ta-bles 1 and 2 .

Table 1. Antibacterial test of n-hexane extract

\begin{tabular}{llll}
\hline \multirow{2}{*}{ Concentrations $(\mu \mathrm{g} / \mathrm{mL})$} & \multicolumn{3}{c}{ Diameter of Clear Zone $(\mathrm{mm})$} \\
\cline { 2 - 4 } Extract of n-Hexane & E.coli & S.aureus & B.subtilis \\
1,9 & 7,80 & - & - \\
3,8 & 9,27 & - & - \\
5,7 & 12,93 & - & - \\
Amoxicillin $(3,8 \mu \mathrm{g} /$ disk $)$ & 19,97 & 11,80 & 17,73 \\
Negative Comparison & - & - & - \\
\hline
\end{tabular}

An antibacterial activity test was performed to determine the presence and absence of antibacterial activity from n-hexane. The method used is gel dif-fusion method. The principle of this method is the direct diffusion test sample to media gel containing the test bacteria with an OD value of 0.1 . The pres-ence of antibacterial activity is characterized by the formation of a clear zone around the test sample. The concentrations of the samples tested were $1.9 \mu \mathrm{g} /$ $\mathrm{mL}, 3.8 \mu \mathrm{g} / \mathrm{mL}$, and $5.7 \mu \mathrm{g} / \mathrm{mL}$. The tested sample was dissolved in a solvent which dissolved the sample, so the solvent was used as a negative control, while the positive control on bacteria was antibiotics, Amoxicillin.

In the disc paper, the sample tested was dropped by $10 \mu \mathrm{L}$ using a micro pipette with concentration variations of $1.9 \mu \mathrm{g} / \mathrm{mL}, 3.8 \mu \mathrm{g} / \mathrm{mL}$ and $5.7 \mu \mathrm{g} / \mathrm{mL}$.then wait until dry. The 
disc paper that has been dropped by the test sample is placed on a gel medi-um (Nutrient gel) which has been solidified for bac-teria. The purpose of drying to evaporate the sol-vent.The sample absorbed in the disc paperso that the sample is expected to have activity as an antibacterial without the solvent used. This preliminary study was conducted to examine the ability of each test sample to kill orto inhibit the test bacteria.

The bacteria tested were two groups of bacteria, one Gram positive (S.aureus and B.subtilis), one Gram negative (E. coli) bacteria. The three microbes were selected because they are commonly used in biological activity tests and there are stocks in the laboratory, and in general they are also the cause of some diseases and infect humans.

The antibacterial activity test of $n$-hexane extract showed the inhibitory zone diameter against E.coli. The drag zone diameters against S.aureus and B.subtiliswere not able to inhibit bacterial growth (Table 1 and Figure 1). This is due to the fact that the n-hexane can dissolves essential oil compounds, saturated and unsaturated fats. So it can damage the outer membrane (membrane outer) composed of proteins, lipoproteins, phospholipids, lipopolysaccharides, and porin (Pratiwi, 2008). Ability to interact and damage the peptidoglycan on Gram negative cell wall bacteria.

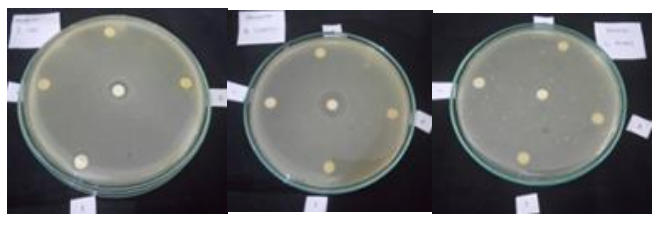

Fig. 1. Anti-bacterial activity test of n-hexane extract

Differences in antibiotic resistance Amoxicillin that occurs in all test bacteria is also due to differ-ences in the components of the bacterial cell wall. Gram-negative bacteria have cell walls containing thin peptidoglycan (one or more layers only), whereas for Gram-positive bacteria having thick cell walls compared with gram-negative bacteria, it comprises 60-100\% peptidoglycan (Pratiwi, 2008).

Gram negative bacteria has a hydrophilic outer and an inner membrane,however grampositive bac-teria has an inner membranes only. This is what causes differences in inhibition of antibiotic Amoxi-cillin for all test bacteria both Gram positive bacteria and Gram negative bacteria (Tiay\&Rahardja, 2002).

Based on the results of the antibacterial activity test showed that n-hexane extracts generally have moderate activity against gram-negative bacteria (E.coli and B.subtilis). For the n-hexane extract, it can inhibit at all test concentrations ranging from 7.80 to $12.93 \mathrm{~mm}$.

If the diameter of the clear zone or inhibit zone is greater than $20 \mathrm{~mm}$ means that the test sample has a strong activity The inhibitory diameter of $16-10 \mathrm{~mm}$ has a moderate activity, a $10 \mathrm{~mm}$ inhibitory diameter has a weak activity and a small inhibitory diameter of 10 has very weak activity (Saxena and Gomber, 2008). This is in contrast to the diameter of the clear zone produced by Amoxicillin in general ranging from $11.80-12.08 \mathrm{~mm}$ and $12.08-19.97 \mathrm{~mm}$ for Gram positive and negative bacteria at concentrations of $3.8 \mu \mathrm{g} / \mathrm{mL}$ indicating that Amoxicillin has activity is.

Tables 1 and 2 shows that the inhibitory power of all test samples increases with the increasing con-centration of the test solution. This shows that the greater the concentration of test solution, the inhibi-tory power of all test samples will be greater. Amox-icillin is a broadspectrum antibiotic derivative of semisynthetic penicillins belonging to the $\beta$-lactam-type 
antibiotic, a class of amphicillin. The $\beta$-lactam antibiotics such as penicillin inhibit bacterial growth by binding to transpeptidase enzymes that sequester the bacterial peptidoglycan wall, thereby weakening the bacterial cell wall (Tortora, 2001). The bacterial cell wall comprises a peptidoglycan network of pol-ymers of amino compounds and sugars that are interconnected with one another (crosslinked) and thus provide mechanical strength to the walls (Pratiwi, 2008).

\section{Conclusion}

It seems that the extract of n-hexane is able to inhibit the highest E.coli bacteria at 5.7 $\mu \mathrm{g} / \mathrm{mL} \mathrm{c}$ with $12.93 \mathrm{~mm}$ inhibition power.

\section{References}

[1] Hwan, K. S., Lee, H. S., Ryu, D. S., Choi, S. J., Lee, D. S., Antibacterial Activity of Silver-nanoparticles Against Staphylococcus aureus and Escherichia coli, Korean J. Microbiol. Biotechnol. (2011)

[2] BachirRaho,B.,Abouni, G.,. Escherichia coli and Staphylococcus aureus most common source of infection, The Battle Against Microbial Pathogens: Basic Science, Technological Advances and Educational Programs.( 2015)

[3] Griffith, K.L., Grossman, A.D.,. Inducible protein degradation in Bacillus subtilis using heterologous peptide tags and adaptor proteins to target substrates to the protease ClpXP, Mol. Microbiol.( 2008)

[4] Abdullah, M., Nesa, M., Islam, R., Banu, Sarkar, J., Islam, N., Bioactivity Studies Of Solanum ferox L Against TriboliumCastaneum (Herbst) Adults, . J. Life Earth Sci.( 2012)

[5] Olmstead, R.G., Bohs, L., Migid, H.A., E. Santiago-valentin, E., Garcia, V.F.,Collier, S.M.,.A Molecular Phylogeny of TheSolanaceae, Taxon 57.( 2008)

[6]Cardenas, P.D., Sonawane, P.D., Heinig, U., Bocobza, S.E., Burdman, S., Aharoni, A.,.The bitter side of the nightshades: Genomics drives discovery in Solanaceae steroidal alkaloid metabolism. Phytochemistry, J. Phytochem. (2015)

[7]Joy, P.P., Thomas, J., Mathew, S., Skaria, B.P., 2001 "Scope of medicinal, aromatic and dye yielding crops in Kerala," In National seminar cum workshop on Scope of medicinal, aromatic and dye yielding crops in dry land agriculture, (Central Research Institute for Dryland Agriculture, Hyderabad, India, 2001).

[8]Rahman, M.S., Rahman, M.Z., Abdul Wahab, M., Chowdhury, R., Rashid, M.A., 2008. Antimicrobial activity of some indigenous plants of Bangladesh, Dhaka Univ. J. Pharm. Sci. 7, 23-26 (2008).

[9]Pratiwi, S.T.,. MikrobiologiFarmasi. Yogyakarta: Erlangga.( 2008)

[10]Tjay, T.H., Rahardja, K.,. Obat-ObatPenting: Khasiat, Penggunaan, Dan EfekEfekSampingnya (V cetakan II ed.). Jakarta: PT. Elex Media Komputindo.( 2002)

[11]Saxena, S., Gomber, C.,. Comparative in vitro Antimicrobial Procedural Efficacy for Susceptibility of Staphylococcus aureus, Escherichia coli and Pseudomonas species to Chloramphenicol, Ciprofloxacin and Cefaclor. British Journal of Biochemical Science(2008)

[12]Tortora, Microbiology. An Intruduction (Fifth ed.). California: Cumming Publishing.( 2001.) 